\title{
EFEK INSENTIF PERPAJAKAN BERDASARKAN DASAR PENGENAAN PAJAK DAN TARIF PAJAK TERHADAP EKONOMI SECARA MAKRO : STUDI KASUS INDONESIA
}

\author{
Ryan Mohammad ${ }^{\mathrm{a}}$, Helmi Zus Rizal ${ }^{\mathrm{b}}$, Gede Satria Pujanggo, PG $^{\mathrm{c}}$ \\ a Direktorat Jenderal Pajak, Denpasar, Indonesia.Email: vermillion.raiha@gmail.com \\ b Direktorat Jenderal Pajak, Denpasar, Indonesia. Email: helmi.zus@gmail.com \\ c Direktorat Jenderal Pajak, Denpasar, Indonesia. Email: gede.satriapg@gmail.com
}

\section{ABSTRACT}

Due to National Economy Recovery program, the Indonesian Government had conducted several Tax Incentive Policies to escalate economic growth faster. However, we have not found any study to measure the policies' effect on macroeconomic indicators. In this paper, we attempt to find the impact of tax incentive policies that had been implemented for the end of the year of 2018. Our purpose is solely to find general understanding and knowledge about tax incentive policies' effect on macro economy. Based on the examination test using The Impulse Response Function method, we discovered that tax incentive policies positively impact investment, gross domestic product, and unemployment. Specifically, tax incentive policies based on tax rates have a better positive impact than tax incentive policies based on tax base. However, those impact only relatively sustains in a short period.

\section{ABSTRAK}

Dalam rangka program Pemulihan Ekonomi Nasional (PEN), Pemerintah Indonesia telah mengeluarkan kebijakan insentif Perpajakan yang bertujuan untuk membantu pemulihan ekonomi lebih cepat. Namun sampai saat ini belum ada yang mengukur pengaruh kebijakan insentif perpajakan terhadap indikator makroekonomi. Penulis berupaya menilai pengaruh kebijakan insentif perpajakan yang ditetapkan di Indonesia hingga sampai dengan per akhir tahun 2018 dengan tujuan untuk memahami pengaruh kebijakan insentif perpajakan pada umumnya terhadap ekonomi secara makro. Berdasarkan hasil pengujian menggunakan metode Impulse Response Function, diketahui insentif pajak secara keseluruhan berdampak positif terhadap variabel investasi, PDB, dan Pengangguran Terbuka. Selain itu, dampak positif insentif pajak berdasarkan tarif pajak terhadap investasi, produk domestik bruto, dan pengangguran terbuka jauh lebih baik apabila dibandingkan dengan Insentif Pajak berdasarkan dasar pengenaan pajak. Namun, dampak positif tersebut relatif bertahan dalam jangka pendek. 


\section{PENDAHULUAN}

Insentif perpajakan merupakan salah satu belanja negara yang umumnya tidak diberikan dalam bentuk uang, melainkan dalam bentuk pengurangan kewajiban perpajakan. Insentif tersebut adalah instrumen fiskal yang biasa digunakan pemerintah untuk meringankan kewajiban perpajakan wajib pajak sektor tertentu, yang harapannya dapat berdampak positif terhadap ekonomi makro secara keseluruhan.

Dalam paper ini, penulis berupaya memahami efek kebijakan insentif perpajakan yang telah ditetapkan sampai dengan per akhir tahun 2018 terhadap indikator makroekonomi. Tujuan penulis mengetahui efek kebijakan tersebut adalah untuk menilai pengaruh insentif perpajakan pada umumnya terhadap ekonomi secara makro yang diharapkan dapat menjadi wawasan untuk mempertajam strategi kebijakan fiskal terkait pemberian insentif perpajakan.

\section{KERANGKA TEORETIS DAN PENGEMBANGAN HIPOTESIS}

\subsection{Belanja Perpajakan}

Dalam rangka menjalankan fungsinya untuk mendorong peningkatan daya saing dan iklim investasi, salah satu upaya pemerintah untuk mewujudkannya adalah menetapkan kebijakan insentif perpajakan dari sisi fiskal. Insentif perpajakan merupakan salah satu bentuk belanja negara yang umumnya tidak diberikan dalam bentuk uang, melainkan berbentuk pengurangan kewajiban, dan lazim disebut sebagai belanja perpajakan (BKF, 2018). Berikut beberapa definisi belanja perpajakan di berbagai negara:

- "Tax Expenditure are defined by law as "revenue losses attributable to provisions of Federal tax law which allow a special exclusion, exemption, or deduction from gross income or which provide a special credit, a preferential rate of tax, or a deferral of tax liability. These exceptions are often viewed as alternatives to other policy instruments, such as spending or regulatory programs." (U.S. Department of the Treasury, 2020).

- "Individual features of the tax system that reduce an entity's tax obligation in a way that is designed to give effect to policy other than to raise revenue in the most efficient and economically neutral way." (New Zealand Treasury Government, 2019).

- "A tax expenditure arises where the tax treatment of an activity or class of taxpayer differs from standard tax treatment that applies to similar taxpayer or types of activity. Tax expenditures typically involve tax exemptions, deductions or offsets, concessional tax rates and deferral of tax liability. In order to determine whether a tax expenditure exists and to estimate the value of the tax expenditure it is first necessary to determine what the standard tax treatment or 'benchmark' is. This choice is inherently subjective and is therefore judgment based. The benchmark in the Tax Expenditure 
Statement has been chosen in a way that attempts to apply a consistent tax treatment to similar taxpayers and similar activities. These judgments are informed by long standing features of the tax system, practice in tax expenditure publications in other jurisdictions and consultation with stakeholders. The choice of benchmark should not be interpreted as an indication of the way activities or taxpayers ought to be taxed." (Australia Department of Treasury, 2017).

- "In broad terms, tax expenditures are concessions that fall outside a tax norm or benchmark. The tax norm includes the rate structure, accounting, conventions, deductibility, and international fiscal obligations. Tax expenditures may take number of forms: exemptions, allowances, credit, preferential tax rates, tax deferrals, and so forth. Tax expenditures reporting measures the revenue that these deviations impart from the tax norm." (OECD, 2016).

- Belanja perpajakan didefinisikan sebagai "penerimaan perpajakan yang hilang atau berkurang sebagai akibat adanya ketentuan khusus yang berbeda dari sistem pemajakan secara umum (benchmark tax system) yang menyasar kepada hanya sebagian subjek dan objek pajak dengan persyaratan tertentu" (BKF, 2018).

Dengan kata lain, belanja perpajakan merupakan ketentuan perpajakan yang menyimpang dari ketentuan perpajakan yang berlaku secara umum (tax benchmark). Dalam praktiknya, tidak seluruh deviasi atas tax benchmark dikategorikan sebagai belanja perpajakan. Badan Kebijakan Fiskal telah menetapkan karakteristik tax benchmark atas PPN dan PPh dalam laporan belanja perpajakan.

\subsection{Benchmark dan Belanja Perpajakan untuk Pajak Pertambahan Nilai dan Pajak Penjualan Barang Mewah (PPN dan PPnBM)}

Karakteristik benchmark system atas PPN dan PPnBM dijelaskan pada Tabel 1.

Deviasi atas seluruh poin di atas dikategorikan sebagai belanja perpajakan. Namun terdapat pengecualian atas ketentuan tersebut apabila terdapat kondisi sebagai berikut:

- Konsumsi akhir yang dilakukan oleh pemerintah.

- Fasilitas yang diberikan pada kegiatan ekonomi yang masih bersifat intermediary process.

- Fasilitas sesuai kelaziman internasional yang sifatnya resiprokal.

- Bertujuan utama untuk memudahkan administrasi perpajakan; atau

- Investasi dalam bentuk uang, emas batangan, dan surat berharga. 
Tabel 1. Karakteristik Benchmark System atas PPN dan PPnBM

\begin{tabular}{|c|c|}
\hline Perihal & Karakteristik \\
\hline Objek Pajak & $\begin{array}{l}\text { Objek PPN: Seluruh barang dan jasa merupakan objek PPN, } \\
\text { kecuali barang/jasa yang telah dikenakan pajak daerah. } \\
\text { Pengecualian ketentuan PPN atas transaksi yang telah } \\
\text { dikenakan pajak daerah tidak termasuk dalam kategori } \\
\text { belanja perpajakan karena pada hakikatnya hanya terjadi } \\
\text { perpindahan hak pemajakan dari pemerintah pusat ke } \\
\text { pemerintah daerah, sehingga secara kumulatif tidak } \\
\text { berdampak pada hilangnya pendapatan negara. } \\
\text { Objek PPnBM: Seluruh barang mewah sesuai dengan } \\
\text { peraturan perundang-undangan. }\end{array}$ \\
\hline Subjek Pajak & $\begin{array}{l}\text { Pihak yang menanggung PPN dan PPnBM adalah konsumen } \\
\text { akhir. }\end{array}$ \\
\hline $\begin{array}{l}\text { Lokasi Pengenaan } \\
\text { Pajak }\end{array}$ & $\begin{array}{l}\text { Tempat konsumsi dilakukan didalam daerah pabean } \\
\text { (destination principle). Dengan demikian insentif PPN dan } \\
\text { PPnBM tidak dipungut atas barang produksi untuk ekspor } \\
\text { tidak termasuk belanja perpajakan. }\end{array}$ \\
\hline Tarif & $\begin{array}{l}\text { Tarif PPN dikenakan dengan tarif standar (10 persen). } \\
\text { Sedangkan PPnBM dikenakan tarif sesuai dengan peraturan } \\
\text { perundang-undangan. }\end{array}$ \\
\hline
\end{tabular}

\subsection{Benchmark dan Belanja Perpajakan untuk Pajak Penghasilan (PPh)}

Karakteristik benchmark system atas PPh dijelaskan sebagai berikut:

Tabel 2. Karakteristik Benchmark System atas PPh

\begin{tabular}{|l|l|}
\hline \multicolumn{1}{|c|}{ Perihal } & \multicolumn{1}{|c|}{ Karakteristik } \\
\hline Objek Pajak & $\begin{array}{l}\text { Objek PPh mencakup seluruh penghasilan, baik yang } \\
\text { diperoleh oleh resident maupun non-resident. Objek pajak } \\
\text { juga bersifat taxable-deductible. Biaya yang dapat } \\
\text { dikurangkan adalah biaya yang digunakan untuk } \\
\text { mendapatkan, menagih, dan memelihara penghasilan. } \\
\text { Penerimaan institusi pemerintah seperti transfer ke } \\
\text { pemerintah daerah dan PNBP dikecualikan dari objek pajak. }\end{array}$ \\
\hline Subjek Pajak & $\begin{array}{l}\text { Pihak yang menanggung PPN dan PPnBM adalah konsumen } \\
\text { akhir. }\end{array}$ \\
\hline Periode & Tahun Pajak \\
\hline Tarif & $\begin{array}{l}\text { Tarif PPh Badan dan Orang Pribadi mengacu pada UU No.36 } \\
\text { Tahun 2008 tentang PPh pasal 17 ayat (1), (2), dan (2a). }\end{array}$ \\
\hline
\end{tabular}


Deviasi atas seluruh poin di atas dikategorikan sebagai belanja perpajakan. Namun terdapat pengecualan atas ketentuan tersebut apabila terdapat kondisi sebagai berikut:

- Tujuan utamanya untuk memudahkan administrasi, seperti pengenaan pajak final atas penghasilan bunga tabungan dan deposito, transaksi penjualan saham di bursa, serta penggunaan norma penghitungan penghasilan neto untuk orang pribadi tertentu.

- Dalam rangka mengikuti konvensi akuntansi seperti Pernyataan Standar Akuntansi Keuangan (PSAK), contohnya perlakuan perpajakan terkait pemupukan dana cadangan untuk perbankan dan asuransi.

Untuk mendukung fungsi pemerintahan atau untuk perjanjian internasional yang bersifat resiprokal, seperti penurunan tarif pajak atas penghasilan tertentu sebagaimana yang disepakati dalam persetujuan penghindaran pajak berganda (P3B) atau tax treaty.

\subsection{Insentif Perpajakan}

Karena sifatnya merupakan deviasi dari ketentuan umum, besaran belanja perpajakan tidak tertera dalam Anggaran Pendapatan dan Belanja Negara (APBN), walaupun sejatinya pengaruh belanja perpajakan sama dengan belanja yang dianggarkan dalam APBN (Uemura, 2009). Oleh karena itu, Badan Kebijakan Fiskal (BKF) melakukan estimasi perhitungan di laporan belanja perpajakan untuk mengukur besaran belanja perpajakan dari insentif perpajakan yang telah diimplementasikan. Insentif perpajakan adalah bentuk belanja perpajakan. Dari segi implementasi kebijakan, insentif perpajakan diterapkan kepada dasar pengenaan pajak atau tarif pajak tertentu. Kedua jenis insentif tersebut secara teoretis memiliki efek yang berbeda terhadap secara ekonomi. Norris dan Frederico (2018) menguji efek insentif perpajakan terhadap indikator makroekonomi seperti: (1) Pendapatan Domestik Bruto (PDB), (2) investasi, (3) konsumsi, dan (4) tingkat pengangguran.

\subsection{Perumusan Masalah}

Gale dan Samwick (2017) menjelaskan bahwa insentif perpajakan berdasarkan dasar pengenaan pajak dapat menimbulkan disrupsi ekonomi lebih rendah dibandingkan insentif perpajakan berdasarkan tarif pajak apabila jumlah sasaran utama dari kelompok wajib pajak yang menerima insentif ini lebih rendah dari jumlah keseluruhan wajib pajak. Hal ini dikarenakan insentif dasar pengenaan pajak cenderung mengarah pada sekelompok wajib pajak yang: (1) termasuk dalam sektor industri tertentu, (2) termasuk dalam kelompok penghasilan rendah, (3) memiliki penghasilan dari berbagai sumber, atau (4) memproduksi produk tertentu yang strategis dan pokok, sedangkan insentif tarif pajak pada umumnya dikenakan hampir ke seluruh jenis wajib pajak.

Kementerian Keuangan Republik Indonesia telah menetapkan 36 insentif perpajakan PPN dan 31 insentif perpajakan PPh sampai dengan per akhir tahun 2018. Kebijakan insentif perpajakan tersebut mencakup perlakuan khusus atas dasar pengenaan pajak tertentu dan tarif pajak 
tertentu. Berdasarkan latar belakang dan landasan teori, penulis merumuskan masalah sebagai berikut:

1. Bagaimana pengaruh seluruh kebijakan insentif perpajakan yang mencakup perlakuan khusus atas dasar pengenaan pajak tertentu dan tarif pajak tertentu yang ditetapkan sampai dengan akhir tahun 2018 terhadap PDB, investasi, konsumsi, dan tingkat pengangguran terbuka?

2. Bagaimana pengaruh seluruh kebijakan insentif perpajakan atas dasar pengenaan pajak tertentu yang ditetapkan sampai dengan akhir tahun 2018 terhadap PDB, investasi, konsumsi, dan tingkat pengangguran terbuka?

3. Bagaimana pengaruh seluruh kebijakan insentif perpajakan yang mencakup perlakuan khusus atas tarif pajak tertentu yang ditetapkan sampai dengan per akhir tahun 2018 terhadap PDB, investasi, konsumsi, atau tingkat pengangguran terbuka?

\section{METODOLOGI PENELITIAN}

\subsection{Metode Seleksi dan Pengumpulan Data}

Penulis menggunakan data sekunder sebagai berikut:

1. Data estimasi nilai insentif perpajakan dari tiap kebijakan insentif berdasarkan Laporan Belanja Perpajakan BKF Tahun 2018;

2. Data Produk Domestik Bruto Indonesia dari tahun 2015 sampai dengan 2019 berdasarkan Laporan Produk Domestik Bruto Triwulanan 2015-2019 Badan Pusat Statistik (BPS);
3. Data investasi, konsumsi, dan belanja pemerintah Indonesia dari tahun 2015 sampai dengan tahun 2019 berdasarkan Berita Resmi Statistik BPS Nomor 16/02/Th.XX Tanggal 16 Februari 2017 dan Nomor 15/02/Th.XXII tanggal 16 Februari 2019;

4. Data pengangguran terbuka indonesia dari tahun 2015 sampai dengan tahun 2019 berdasarkan Laporan Keadaan Angkatan Kerja di Indonesia oleh BPS;

5. Data inflasi Indonesia dari tahun 2015 sampai dengan tahun 2019 berdasarkan website OECD: data.oecd.org/price/ inflation-cpi.htm yang diakses pada tanggal 16 September 2020;

6. Data tingkat suku bunga Bank Indonesia (BI) per kuartal dari tahun 2015 sampai dengan tahun 2019 berdasarkan website Bank Indonesia: https://www.bi.go.id/id/ lip/infografis yang diakses pada tanggal 16 September 2020;

7. Data utang pemerintah Indonesia per kuartal dari tahun 2015 sampai dengan tahun 2019 berdasarkan website BI: https://www.bi.go.id/id/statistik/suspi/ Default.aspx yang diakses pada tanggal 16 September 2020; dan

8. Data penerimaan nasional dari tahun 2015 sampai dengan tahun 2019 berdasarkan Laporan Keuangan Pemerintah Pusat tahun 2015 sampai dengan tahun 2019.

\subsection{Definisi Operasional Variabel}

Norris dan Frederico (2018) menjelaskan bahwa terdapat tiga jenis insentif perpajakan yang dijelaskan sebagai berikut :

1. Insentif perpajakan secara keseluruhan adalah total kerugian penerimaan pajak 
yang berasal dari insentif pajak berdasarkan dasar pengenaan pajak dan tarif pajak per kuartal dibagi dengan PDB per kuartal.

2. Insentif perpajakan berdasarkan dasar pengenaan pajak adalah total kerugian penerimaan pajak yang berasal hanya dari insentif perpajakan berdasarkan dasar pengenaan pajak per kuartal dibagi dengan PDB per kuartal.

3. Insentif perpajakan berdasarkan tarif pajak adalah total kerugian penerimaan pajak yang berasal hanya dari insentif perpajakan berdasarkan tarif pajak per kuartal dibagi dengan PDB per kuartal

\subsection{Metode Analisis Data}

Norris dan Frederico (2018) terlebih dahulu melakukan pengujian atas variabel insentif perpajakan secara keseluruhan, variabel insentif pajak berdasarkan dasar pengenaan pajak, dan variabel insentif pajak berdasarkan tarif pajak dengan variabel, PDB, inflasi, tingkat suku bunga, utang pemerintah, belanja pemerintah, dan penerimaan negara menggunakan metode Pairwise Granger Causality Test. Granger (1969) menjelaskan bahwa metode Pairwise Granger Causality Test adalah tes uji hipotesis statistik yang menentukan apakah suatu data deret waktu dapat memperkirakan data deret waktu lainnya dengan mempertimbangkan banyaknya lag dalam tiap variabel yang diuji. Pengujian Pairwise Granger Causality Test bertujuan untuk menentukan apakah variabel PDB, inflasi, tingkat suku bunga, utang pemerintah, belanja pemerintah, dan penerimaan negara memiliki korelasi dan dapat memprediksi variabel insentif perpajakan.

Setelah proses pengujian tersebut, Norris dan Frederico (2018) melakukan pengukuran atas pengaruh variabel insentif perpajakan terhadap variabel PDB, investasi, konsumsi, dan tingkat pengangguran menggunakan model Vector Autoregression (VAR) fungsi Impulse Response. Pindyck dan Rubinfield (1991) menjelaskan bahwa Impulse Response Function adalah metode yang dapat digunakan untuk menentukan respons suatu variabel endogen terhadap shock variabel tertentu. Seluruh metode analisis data penulis olah menggunakan aplikasi statistik eviews version 9.0.

\section{HASIL DAN PEMBAHASAN}

\subsection{Data Riset}

BKF (2018) mengukur nilai insentif perpajakan menggunakan revenue forgone method. Metode ini mengasumsikan bahwa estimasi yang dilakukan bersifat statis. Penulis hanya menggunakan 29 dari 36 estimasi nilai Insentif PPN dan 18 dari 31 estimasi nilai Insentif PPh karena tidak seluruh kebijakan insentif perpajakan dapat diestimasikan nilainya oleh BKF. Penulis juga membagi tiap nilai estimasi kebijakan tersebut ke dua kelompok, yaitu insentif perpajakan berdasarkan dasar pengenaan pajak dan insentif perpajakan berdasarkan tarif pajak. Total nilai insentif pajak dan PDB disajikan penulis dalam tabel sebagai berikut (rincian data nilai insentif pajak per kebijakan disajikan di lampiran): 
Tabel 3. Nilai Insentif Pajak dan Produk Domestik Bruto

Sumber: Laporan Belanja Perpajakan BKF Tahun 2018 dan Laporan Produk Domestik Bruto BPS

Tahun 2016-2018

(dalam triliun rupiah)

\begin{tabular}{|l|c|c|c|}
\hline \multirow{2}{*}{} & \multicolumn{3}{|c|}{ Tahun } \\
\cline { 2 - 4 } & $\mathbf{2 0 1 6}$ & $\mathbf{2 0 1 7}$ & $\mathbf{2 0 1 8}$ \\
\hline Insentif Pajak secara Keseluruhan & 155,008 & 175,720 & 196,736 \\
\hline Insentif Pajak (Dasar Pengenaan Pajak) & 135,715 & 153,449 & 167,371 \\
\hline Insentif Pajak (Tarif Pajak) & 19,293 & 22,271 & 29,365 \\
\hline PDB & $12.406,8$ & $13.588,8$ & $14.837,4$ \\
\hline Persentase Insentif Pajak terhadap PDB & $1,25 \%$ & $1,29 \%$ & $1,33 \%$ \\
\hline
\end{tabular}

\subsection{Pengujian Insentif Perpajakan}

Norris dan Frederico (2018) menerapkan metode Pairwise Granger Casualty Test atas insentif perpajakan dengan lag sejumlah 4. Penulis menerapkan metode Pairwise Granger Casualty Test dengan lag yang sama atas variabel insentif perpajakan secara keseluruhan, variabel insentif perpajakan berdasarkan dasar pengenaan pajak, dan variabel insentif perpajakan berdasarkan tarif pajak secara tersendiri terhadap variabel inflasi, tingkat suku bunga, utang pemerintah, PDB, dan penerimaan negara.

Berdasarkan hasil pengujian, diketahui nilai F-statistik (kolom atas) dan probabilitas (kolom bawah) tiap variabel, sehingga disimpulkan bahwa ketiga variabel insentif perpajakan tidak berkorelasi dan tidak dapat diprediksi oleh variabel inflasi, tingkat suku bunga, utang pemerintah, PDB, dan penerimaan negara. Apabila variabel insentif perpajakan tidak berkorelasi dan tidak dapat diprediksi oleh variabel-variabel tersebut, maka pengujian efek Insentif Perpajakan menggunakan metode Impulse Response Function dapat dilakukan. Penulis menyajikan hasil pengujian Granger Casualty Test di tabel 4. Rincian hasil pengujian per variabel penulis sajikan di lampiran.

Tabel 4. Hasil Granger Causality Test

Sumber: data diolah dengan program statistik esviews version 9.0

\begin{tabular}{|c|c|c|c|c|c|c|}
\hline \multirow{2}{*}{ Regressor } & PDB & Inflasi & $\begin{array}{c}\text { Suku } \\
\text { Bunga }\end{array}$ & $\begin{array}{c}\text { Utang } \\
\text { Pemerintah }\end{array}$ & $\begin{array}{c}\text { Belanja } \\
\text { Pemerintah }\end{array}$ & $\begin{array}{c}\text { Penerimaan } \\
\text { Negara }\end{array}$ \\
\hline \multirow{2}{*}{ IP Semua } & 0,22 & 0,14 & 0,00 & 3,40 & 3,05 & 3,69 \\
\cline { 2 - 7 } & 0,91 & 0,95 & 0,00 & 0,08 & 0,10 & 0,07 \\
\hline \multirow{2}{*}{ IP DPP } & 0,04 & 1,19 & 0,45 & 0,48 & 1,37 & 2,46 \\
\cline { 2 - 7 } & 0,99 & 0,40 & 0,76 & 0,75 & 0,34 & 0,15 \\
\hline \multirow{2}{*}{ IP Tarif } & 1,31 & 0,61 & 10,28 & 3,08 & 1,60 & 1,06 \\
\cline { 2 - 7 } & 0,36 & 0,66 & 0,007 & 0,10 & 0,28 & 0,44 \\
\hline
\end{tabular}




\subsection{Efek Insentif Perpajakan dengan Metode VAR Impulse Response Function}

Dalam rangka menjawab rumusan masalah pertama, Penulis menguji efek variabel Insentif Perpajakan secara keseluruhan terhadap variabel investasi, konsumsi, PDB, dan pengangguran terbuka menggunakan metode VAR Impulse Response Function. Besaran efek variabel insentif perpajakan tersebut setara dengan $1 \%$ atau lebih dari PDB dengan tingkat interval konfiden 68 persen dan 90 persen dan jangka waktu perkiraan selama 16 periode, dimana satu periode dihitung satu kuartal. Dua garis merah yang mengapit garis biru dalam grafik menunjukkan rentang interval konfiden.

Dari sisi investasi, efek insentif pajak secara keseluruhan memperkirakan penurunan terhadap investasi di kuartal kedua yang kemudian naik kembali di kuartal tiga. Inventasi diperkirkan fluktuatif turun dan naik dari kuartal tiga sampai kuartal dua belas hingga akhirnya tidak mengalami perubahan signifikan secara statistik sampai kuartal 16.

Dari sisi PDB, efek insentif
pajak
secara memperkirakan peningkatan PDB di kuartal kedua, lalu penurunan di kuartal ketiga, kemudian peningkatan secara konstan hingga kuartal enam. PDB diperkirakan menurun sedikit di kuartal enam tetapi meningkat lagi di kuartal ketujuh hingga akhirnya bertahan di posisi sekitar 0,4\% dari PDB sampai kuartal 16.

Dari sisi konsumsi, efek insentif pajak secara keseluruhan memperkirakan fluktuasi dari kuartal kedua sampai kuartal kedelapan. Konsumsi diperkirakan tidak mengalami perubahan signifikan secara statistik dari kuartal delapan hingga kuartal 16.

Dari sisi pengangguran terbuka, efek insentif pajak secara keseluruhan memperkirakan penurunan di kuartal kedua, yang kemudian naik perlahan dari kuartal tiga hingga meningkat tajam di kuartal kelima. Namun pengangguran terbuka diperkirakan turun kembali di kuartal enam hingga kuartal delapan, lalu konstan di titik tertentu dari kuartal sepuluh hingga kuartal 16. Penulis menyajikan pergerakan perkiraan tiap variabel tersebut dalam Grafik 1.

Dalam rangka menjawab rumusan masalah ketiga, penulis menguji efek variabel insentif perpajakan berdasarkan tarif pajak terhadap variabel investasi, konsumsi, PDB, dan pengangguran terbuka menggunakan metode VAR Impulse Response Function. Besaran efek variabel insentif perpajakan tersebut setara dengan 1\% atau lebih dari PDB dengan tingkat interval konfiden 68 persen dan 90 persen dan jangka waktu perkiraan selama 16 periode, dimana satu periode dihitung satu kuartal. Dua garis merah yang mengapit garis biru dalam grafik menunjukkan rentang interval konfiden. 
Grafik 1. Grafik Efek Insentif Pajak Secara Keseluruhan Terhadap Investasi, PDB, Konsumsi, dan Pengangguran Terbuka

Sumber: data diolah dengan program statistik eviews version 9.0

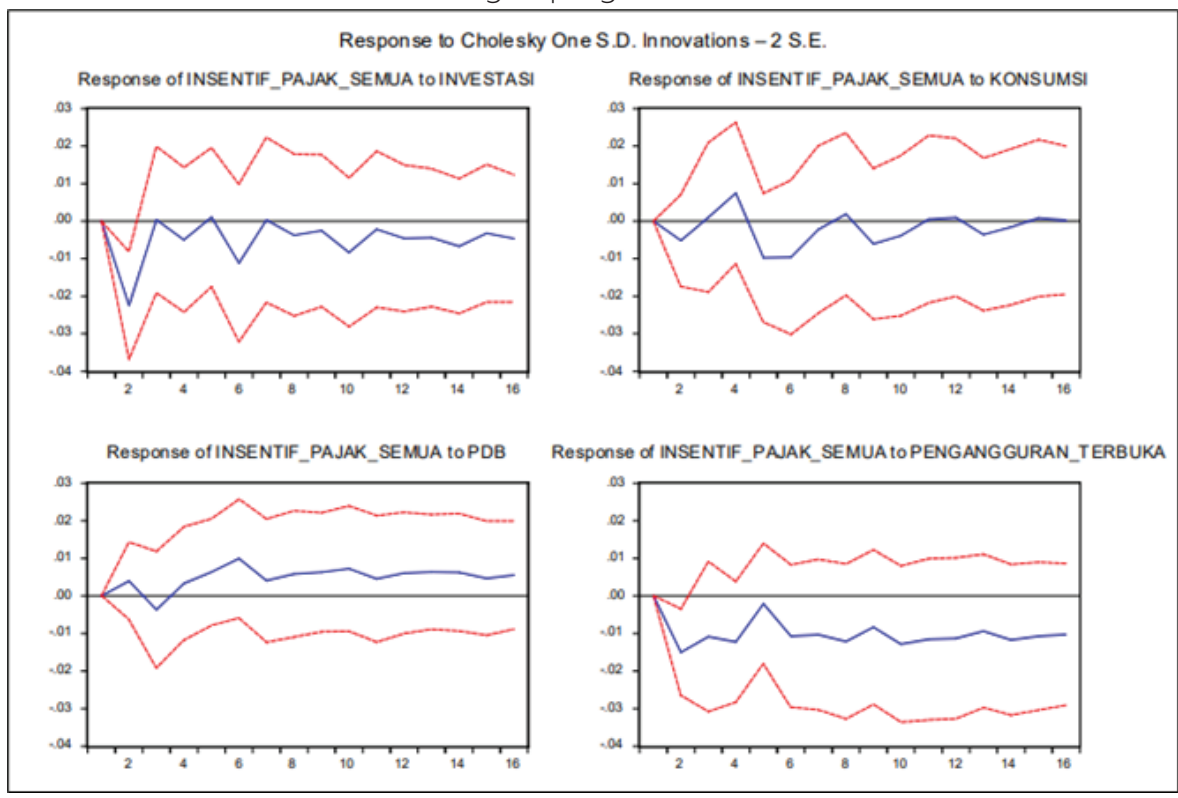

Dari sisi investasi, insentif pajak berdasarkan dasar pengenaan pajak memperkirakan penurunan investasi di kuartal kedua, lalu meningkat di kuartal ketiga yang bertahan konstan hingga kuartal lima. Investasi diperkirakan tidak mengalami perubahan signifikan secara statistik dari kuartal enam hingga kuartal 16.

Dari sisi PDB, insentif pajak berdasarkan dasar pengenaan pajak memperkirakan peningkatan PDB di kuartal kedua, lalu mengalami penurunan di kuartal ketiga. PDB diperkirakan meningkat lagi di kuartal enam, tetapi tidak mengalami perubahan signifikan secara statistik di kuartal tujuh hingga kuartal 16.

Dari sisi konsumsi, insentif pajak berdasarkan dasar pengenaan pajak memperkirakan penurunan konsumsi hingga di ketiga, lalu meningkat di kuartal empat. Konsumsi diperkirkan kembali menurun di kuartal kelima yang kemudian tidak mengalami perubahan signifikan secara statistik dari kuartal enam hingga kuartal 16.

Dari sisi pengangguran terbuka, insentif perpajakan berdasarkan dasar pengenaan pajak menurun di kuartal kedua, lalu meningkat di kuartal empat. Pengangguran terbuka diperkirakan akan menurun lagi di kuartal enam, lalu meningkat lagi hingga kuartal tujuh, yang kemudian tidak berubah secara signifikan dari kuartal tujuh sampai kuartal 16. Penulis menyajikan pergerakan perkiraan tiap variabel tersebut dalam Grafik 2. 
Grafik 2. Grafik Efek Insentif Pajak Berdasarkan Dasar Pengenaan Pajak Terhadap Investasi, PDB, Konsumsi, dan Pengangguran Terbuka

Sumber: data diolah dengan program statistik eviews version 9.0

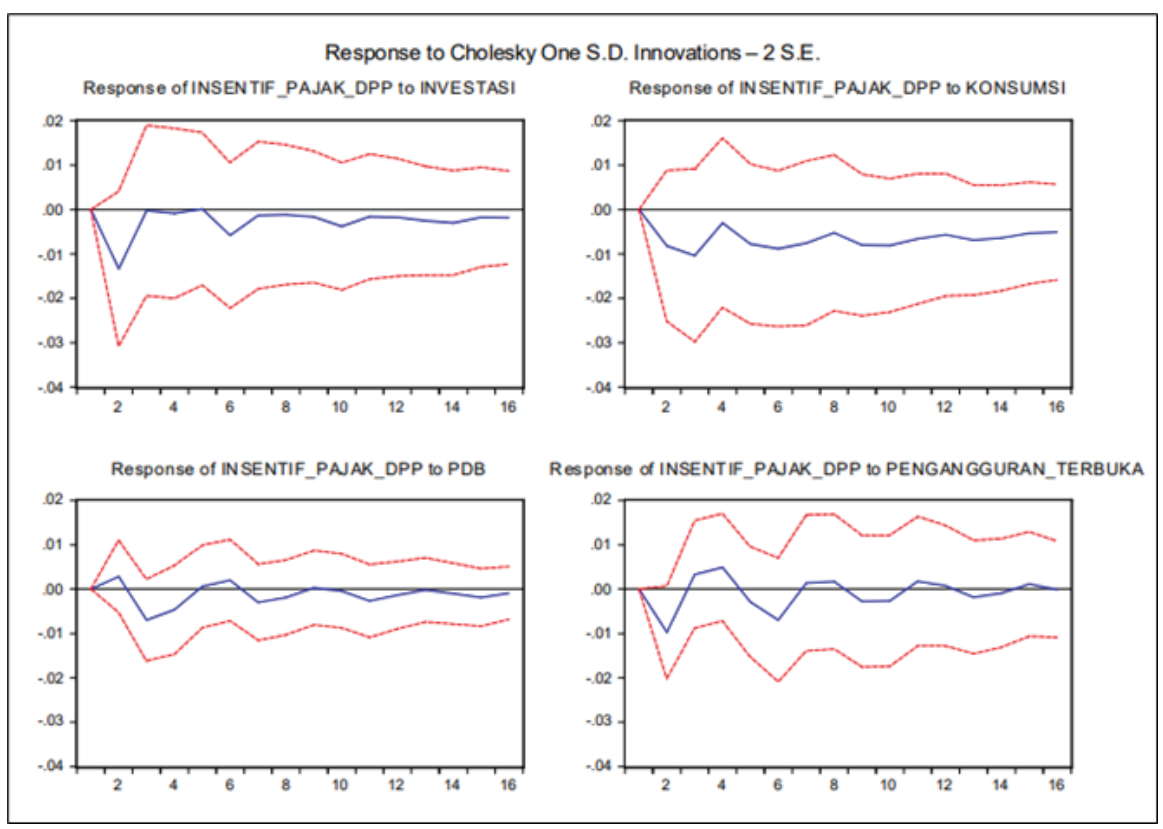

Dalam rangka menjawab rumusan masalah ketiga, penulis menguji efek variabel insentif perpajakan berdasarkan tarif pajak terhadap variabel investasi, konsumsi, PDB, dan pengangguran terbuka menggunakan metode VAR Impulse Response Function. Besaran efek variabel insentif perpajakan tersebut setara dengan 1\% atau lebih dari PDB dengan tingkat interval konfiden 68 persen dan 90 persen dan jangka waktu perkiraan selama 16 periode, dimana satu periode dihitung satu kuartal. Dua garis merah yang mengapit garis biru dalam grafik menunjukkan rentang interval konfiden.

Dari sisi investasi, insentif pajak berdasarkan tarif pajak memperkirakan penurunan investasi di kuartal kedua, lalu peningkatan cukup signifikan di kuartal tiga. Investasi diperkirakan fluktuatif dari kuartal tiga sampai dengan delapan, lalu tidak lagi mengalami perubahan signifikan secara statistik dari kuartal Sembilan hingga kuartal 16.

Dari sisi konsumsi, insentif pajak berdasarkan tarif pajak memperkirakan penurunan perlahan mulai dari kuartal dua hingga kuartal lima lalu kembali naik perlahan hingga kuartal sebelas. Konsumsi diperkirakan tidak mengalami perubahan signifikan dari kuartal 12 hingga 16.

Dari sisi PDB, insentif pajak berdasarkan tarif pajak memperkirakan penurunan di kuartal dua, lalu peningkatan cukup signifikan di kuartal lima. PDB diperkirkan fluktuatif dari kuartal enam hingga kuartal 10, lalu bertahan di posisi sekitar 2\% dari PDB dari kuartal 11 hingga kuartal 16. 
Dari sisi pengangguran terbuka, insentif pajak berdasarkan tarif pajak memperkirakan

penurunan pengangguran terbuka di kuartal dua, lalu meningkat lagi di kuartal empat. Pengangguran terbuka kembali menurun di kuartal lima, sampai akhirnya tidak mengalami perubahan signifikan secara statistik dari kuartal enam hingga kuartal 16. Penulis menyajikan pergerakan perkiraan tiap variabel tersebut dalam Grafik 3.

Grafik 3. Grafik Efek Insentif Pajak Berdasarkan Tarif Pajak terhadap Investasi, PDB, Konsumsi, dan Pengangguran Terbuka

Sumber: data diolah dengan program statistik eviews version 9.0

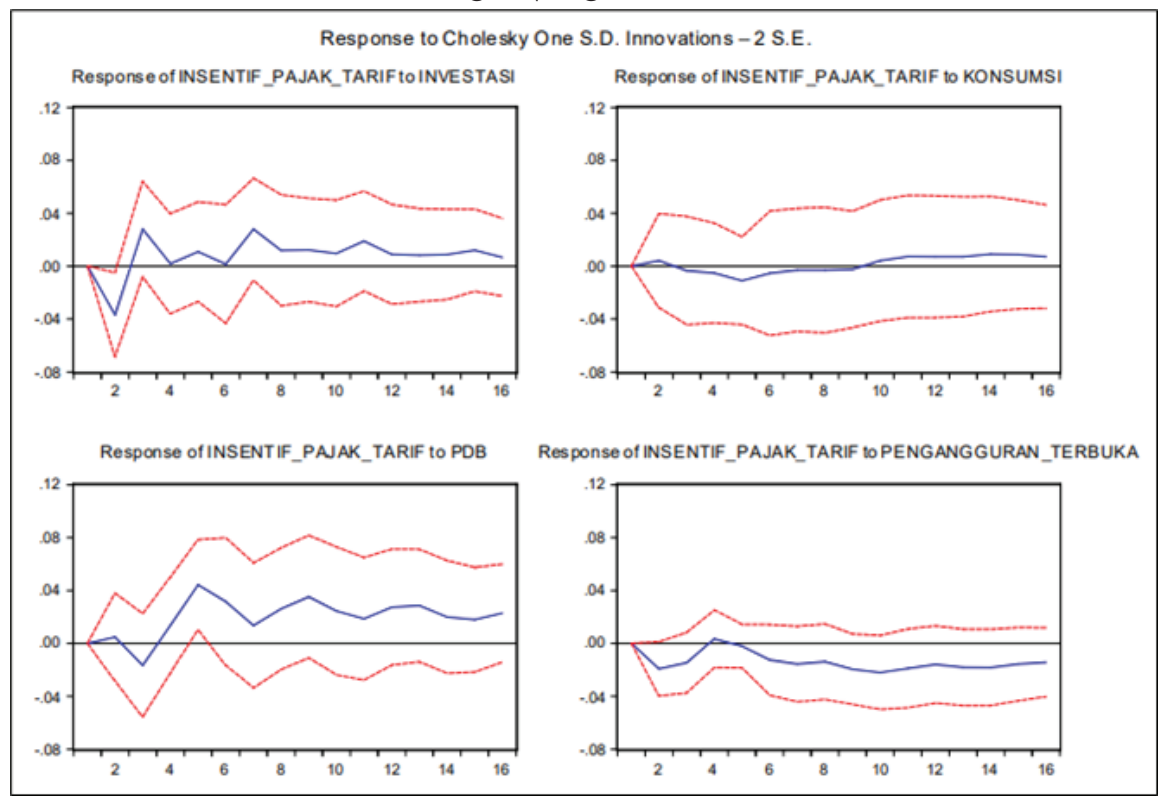

\section{KESIMPULAN}

Berdasarkan hasil pengujian, penulis menyimpulkan bahwa insentif perpajakan secara keseluruhan berdampak positif terhadap indikator makroekonomi seperti investasi, PDB, dan pengangguran terbuka, tetapi tidak berdampak signifikan terhadap konsumsi. Insentif perpajakan berdasarkan tarif pajak memberikan dampak yang positif lebih baik atas investasi, PDB, dan pengangguran terbuka apabila dibandingkan dengan insentif perpajakan berdasarkan dasar pengenaan pajak. Hal ini sesuai dengan temuan Gale dan Samwick (2017) yang menjelaskan bahwa insentif pajak berdasarkan dasar pengenaan pajak memiliki efek disrupsi relatif rendah terhadap terhadap sisi ekonomi secara makro. Namun demikian, insentif perpajakan terprediksi tidak dapat memberikan dampak positif dalam jangka panjang. Hal ini terbukti dari indikator makroekonomi yang relatif stagnan saat mencapai kuartal diatas 4 atau 6. 
Diberlakukannya banyak insentif perpajakan baru dalam rangka Program Pemulihan Ekonomi Nasional (PEN) di tahun 2019 dan 2020 diprediksi dapat mendorong pertumbuhan ekonomi ke arah positif. Namun secara umum, dapat diketahui bahwa insentif perpajakan hanya memberikan dampak positif dalam jangka pendek (kurang lebih 4 sampai 6 kuartal) terhadap pertumbuhan ekonomi secara makro.

\section{IMPLIKASI DAN KETERBATASAN}

Penulis memiliki keterbatasan sumber daya, waktu, dan data dalam penelitian ini. Implikasi temuan penulis terbatas hanya dari kebijakan insentif perpajakan yang diberlakukan sampai dengan akhir tahun 2018 karena penulis hanya menggunakan Laporan Belanja Perpajakan BKF tahun 2018 untuk definisi belanja perpajakan sebagai proxy nilai insentif perpajakan dan estimasi nilai dari tiap insentif tersebut. Saran penulis untuk penelitian berikutnya adalah penelitian dapat dikembangkan apabila data nilai estimasi insentif perpajakan tahun 2019 ke atas telah tersedia dan dampak insentif perpajakan dapat dikelompokkan lagi berdasarkan jenis pajak, seperti: PPh dan PPN. Penelitian juga dapat dikembangkan dengan melibatkan analisis dampak insentif perpajakan baru dalam rangka program PEN seperti PPh 21 Ditanggung Pemerintah (DTP), PPh untuk UMKM dengan peredaran bruto tertentu DTP, dan PPh 22 dibebaskan.

Selain itu, nilai insentif perpajakan yang diukur dalam laporan belanja perpajakan BKF menggunakan metode revenue forgone adalah penilaian yang paling konservatif di antara tiga metode biasa digunakan. Penulis menyarankan apabila datanya telah tersedia, maka penelitian selanjutnya dapat dikembangkan dengan pengukuran estimasi nilai insentif perpajakan menggunakan metode Final Revenue Loss yang mempertimbangkan perubahan perilaku wajib pajak dan penerimaan pajak lainnya setelah ada insentif perpajakan.

\section{DAFTAR PUSTAKA}

[1] Australia Department of the Treasury. (2017). Tax Expenditure Statement Fiscal year of 2017. Retrieved from https://treasury.gov.au/sites/ default/files/ 2019-03/2017-TES.pdf.

[2] Badan Kebijakan Fiskal Kementerian Keuangan. (2019). Laporan Belanja Perpajakan 2018. Jakarta: Badan Kebijakan Fiskal Kementerian Keuangan.

[3] Gale, W. G., \& Samwick, A. A. (2017). Effect of Income Tax Changes on Economic Growth. The Economic of Tax Policy.

[4] Granger, C. W. (1969). Investigating Causal Relations by Econometric Models and Cross-spectral Methods. Econometrica, 37(3), 424-438. doi:doi:10.2307/1912791.

[5] New Zealand Department of the Treasury. (2020). Tax Expenditure Statement Fiscal Year 2019. New Zealand Department of the Treasury. Retrieved from https://www. treasury.govt.nz/sites/default/files/2019-05/b1 9-taxexpstmt.pdf.

[6] Norris, E. D., \& Lima, F. (2018). Macroeconomic Effects of Tax Rate and Base Changes: Evidence from Fiscal Consolidation. Washington, D.C., Washington, D.C., USA: International Monetary Fund. Retrieved from https://www.imf.org/en/Publications/WP/Issue s/2018/09/28/Macroeconomic-Effects-of-TaxRate-and-Base-Changes-Evidence-from-Fisca I-Consolidations. 
Ryan Mohammad, Helmi Zus Rizal, Gede Satria Pujanggo, PG / Efek Insentif Perpajakan... (2021) 179-198

[7] Organisation for Economic Co-operation and Development (OECD). (1996). Tax Expenditure,recent experiences. Paris: OECD Committee on Fiscal Affairs.

[8] Pindyck, R., \& Rubinfeld, D. (1991). Econometric Models and Economic Forecast. Boston: McGraw-Hill Irwin.

U.S. Department of the Treasury. (2020). Tax

[9] Expenditure Statement Fiscal Year 2020. Retrieved from U.S. Department of the Treasury: https://home.treasury.gov/system /files/131/Tax-Expenditures-2021.pdf. 


\section{LAMPIRAN}

\section{Estimasi Nilai Insentif Perpajakan 2016 - 2018}

\begin{tabular}{|c|c|c|c|c|c|c|}
\hline Kebijakan & Peraturan & $\begin{array}{l}\text { Jenis } \\
\text { Pajak }\end{array}$ & Tipe & 2016 & 2017 & 2018 \\
\hline $\begin{array}{l}\text { PPN tidak terutang } \\
\text { (Dibawah 4,8 Miliar) }\end{array}$ & $\begin{array}{l}\text { PMK- } \\
\text { no.197/PMK.03/2013 }\end{array}$ & PPN & DPP & 32.946 & 39.043 & 44.254 \\
\hline $\begin{array}{l}\text { PPN tidak terutang atas } \\
\text { barang kebutuhan pokok }\end{array}$ & UU No.42/2009 & PPN & DPP & 20.863 & 21.476 & 22.070 \\
\hline $\begin{array}{l}\text { PPN tidak terutang atas jasa } \\
\text { pelayanan kesehatan medis }\end{array}$ & UU No.42/2009 & PPN & DPP & 2.798 & 3.207 & 4.401 \\
\hline $\begin{array}{l}\text { PPN tidak terutang atas jasa } \\
\text { pelayanan sosial }\end{array}$ & UU No.42/2009 & PPN & DPP & 397 & 432 & 471 \\
\hline $\begin{array}{l}\text { PPN tidak terutang atas jasa } \\
\text { pengiriman surat dengan } \\
\text { prangko }\end{array}$ & UU No.42/2009 & PPN & DPP & 3 & 2 & 2 \\
\hline $\begin{array}{l}\text { PPN tidak terutang atas Jasa } \\
\text { Keuangan }\end{array}$ & UU No.42/2009 & PPN & DPP & 7.774 & 8.204 & 8.547 \\
\hline $\begin{array}{l}\text { PPN tidak terutang atas Jasa } \\
\text { Asuransi }\end{array}$ & UU No.42/2009 & PPN & DPP & 1.304 & 2.197 & 3.982 \\
\hline $\begin{array}{l}\text { PPN tidak terutang atas jasa } \\
\text { keagamaan }\end{array}$ & UU No.42/2009 & PPN & DPP & 128 & 199 & 216 \\
\hline $\begin{array}{l}\text { PPN tidak terutang atas jasa } \\
\text { pendidikan }\end{array}$ & UU No.42/2009 & PPN & DPP & 8.084 & 8.677 & 10.881 \\
\hline $\begin{array}{l}\text { PPN tidak terutang atas jasa } \\
\text { angkutan umum }\end{array}$ & UU No.42/2009 & PPN & DPP & 11.822 & 12.670 & 13.577 \\
\hline $\begin{array}{l}\text { PPN tidak terutang atas jasa } \\
\text { pengiriman uang dengan } \\
\text { wesel pos }\end{array}$ & UU No.42/2009 & PPN & DPP & 112 & 97 & 90 \\
\hline $\begin{array}{l}\text { PPN dan PPnBm tidak } \\
\text { dipungut atas impor barang } \\
\text { badan internasional yang } \\
\text { terdaftar pada Pemerintah } \\
\text { Indonesia beserta para } \\
\text { pejabatnya yang bertugas di } \\
\text { Indonesia dan tidak } \\
\text { memegang paspor } \\
\text { Indonesia }\end{array}$ & $\begin{array}{l}\text { PMK No. } \\
\text { 137/PMK.010/2018 }\end{array}$ & PPN & DPP & 5 & 4 & 4 \\
\hline $\begin{array}{l}\text { PPN dan PPnBM tidak } \\
\text { dipungut atas impor barang } \\
\text { keperluan penelitian dan } \\
\text { pengembangan ilmu } \\
\text { pengetahuan }\end{array}$ & $\begin{array}{l}\text { PMK No. } \\
\text { 137/PMK.010/2018 }\end{array}$ & PPN & DPP & 20 & 12 & 11 \\
\hline $\begin{array}{l}\text { PPN dan PPnBM tidak } \\
\text { dipungut atas impor barang } \\
\text { keperluan museum, kebun } \\
\text { binatang dan barang untuk } \\
\text { konversi alam }\end{array}$ & $\begin{array}{l}\text { PMK No. } \\
\text { 137/PMK.010/2018 }\end{array}$ & PPN & DPP & - & - & 4 \\
\hline
\end{tabular}




\begin{tabular}{|c|c|c|c|c|c|c|}
\hline $\begin{array}{l}\text { PPN dan PPnBM tidak } \\
\text { dipungut atas barang } \\
\text { pribadi penumpang, awak } \\
\text { sarana pengangkut, pelintas } \\
\text { batas dan barang kiriman } \\
\text { sampai jumlah tertentu }\end{array}$ & $\begin{array}{l}\text { PMK No. } \\
\text { 137/PMK.010/2018 }\end{array}$ & PPN & DPP & - & 5.215 & 3.951 \\
\hline $\begin{array}{l}\text { PPN Dibebaskan atas buku- } \\
\text { buku pelajaran umum, kitab } \\
\text { suci dan buku-buku } \\
\text { pelajaran agama }\end{array}$ & PP No. 38 Tahun 2003 & PPN & DPP & 359 & 419 & 38 \\
\hline $\begin{array}{l}\text { PPN dibebaskan atas } \\
\text { penyerahan rumah } \\
\text { sederhana, rumah sangat } \\
\text { sederhana, rumah rusun } \\
\text { sederhana, ponok boro, } \\
\text { asrama mahasiswa dan } \\
\text { pelajar, serta perumahan } \\
\text { lainnya }\end{array}$ & PP No. 38 Tahun 2003 & PPN & DPP & 297 & 324 & 364 \\
\hline $\begin{array}{l}\text { PPN dibebaskan atas jasa } \\
\text { yang diserahkan oleh } \\
\text { kontraktor untuk } \\
\text { pemborongan bangunan } \\
\text { rumah sederhana dna } \\
\text { sangat sederhana dan } \\
\text { pembangunan tempat yang } \\
\text { semata-mata untuk } \\
\text { keperluan ibadah }\end{array}$ & PP No. 38 Tahun 2003 & PPN & DPP & 84 & 127 & 166 \\
\hline $\begin{array}{l}\text { PPN dibebaskan atas barang } \\
\text { yang dihasilkan dari } \\
\text { kegiatan usaha kelautan, } \\
\text { perikanan, pertanian, } \\
\text { peternakan, perkebunan } \\
\text { serta benih, bibit, dan } \\
\text { pakannya }\end{array}$ & PP No. 81 Tahun 2015 & PPN & DPP & 13.566 & 14.246 & 14.927 \\
\hline $\begin{array}{l}\text { PPN dibabaskan atas listrik, } \\
\text { kecuali untuk rumah dengan } \\
\text { daya di atas } 6600 \text { VA }\end{array}$ & PP No. 81 Tahun 2015 & PPN & DPP & 11.994 & 12.335 & 12.917 \\
\hline $\begin{array}{l}\text { PPN dibebaskan atas air } \\
\text { bersih }\end{array}$ & PP No. 40 Tahun 2015 & PPN & DPP & 468 & 500 & 547 \\
\hline $\begin{array}{l}\text { PPN dan PPnBM dibebaskan } \\
\text { atas penyerahan yang } \\
\text { dilakukan di kawasan } \\
\text { perdagangan bebas dan } \\
\text { pelabuhan bebas }\end{array}$ & PP No. 10 Tahun 2012 & PPN & DPP & 1.359 & 1.438 & 1.494 \\
\hline $\begin{array}{l}\text { Pengurangan Dasar } \\
\text { Pengenaan Pajak PPnBM } \\
\text { sebesar } 0 \text { persen dari harga } \\
\text { jual untuk kendaraan } \\
\text { bermotor termasuk } \\
\text { program mobil hemat } \\
\text { energi dan harga terjangkau } \\
\text { (LCGC), selain sedan atau } \\
\text { station wagon }\end{array}$ & PP No. 41 Tahun 2013 & PPN & DPP & 1.940 & 2.009 & 2.349 \\
\hline
\end{tabular}




\begin{tabular}{|c|c|c|c|c|c|c|}
\hline $\begin{array}{l}\text { Tax Holiday untuk industri } \\
\text { pionir }\end{array}$ & $\begin{array}{l}\text { PMK-35/PMK- } \\
010 / 2018\end{array}$ & PPh & DPP & - & - & 1.111 \\
\hline $\begin{array}{l}\text { Investment Allowance untuk } \\
\text { penanaman modal bidang } \\
\text { usaha tertentu dan/atau di } \\
\text { daerah tertentu (tax } \\
\text { allowance) }\end{array}$ & $\begin{array}{l}\text { Pasal 31A UU No. } 36 \\
\text { Tahun } 2008\end{array}$ & PPh & DPP & 1.059 & 1.028 & 791 \\
\hline $\begin{array}{l}\text { Penurunan tarif PPh bagi } \\
\text { Perseroan Terbuka }\end{array}$ & $\begin{array}{l}\text { Pasal } 17 \text { ayat }(2 b) \text { UU } \\
\text { No. } 36 \text { Tahun } 2008\end{array}$ & $\mathrm{PPh}$ & Tarif & 7.077 & 7.488 & 7.927 \\
\hline $\begin{array}{l}\text { Pengurangan } 50 \text { persen tarif } \\
\text { PPh Bagi WP Badan }\end{array}$ & $\begin{array}{l}\text { Pasal 31E UU No. } 36 \\
\text { Tahun } 2008\end{array}$ & $\mathrm{PPh}$ & Tarif & 2.541 & 2.676 & 2.291 \\
\hline $\begin{array}{l}\text { Fasilitas PPh ditanggung } \\
\text { Pemerintah atas bunga atau } \\
\text { imbalan surat berharga } \\
\text { negara yang diterbitkan di } \\
\text { pasar internasional dan } \\
\text { penghasilan pihak ketiga } \\
\text { atas jasa yang diberikan } \\
\text { kepada pemerintah dalam } \\
\text { penerbitan dan/atau } \\
\text { pembelian } \\
\text { kembali/penukaran surat } \\
\text { berharga negara di pasar } \\
\text { internasional }\end{array}$ & $\begin{array}{l}\text { PMK } \\
\text { No.126/PMK.010/2017 }\end{array}$ & $\mathrm{PPh}$ & DPP & 7.138 & 7.230 & 8.218 \\
\hline $\begin{array}{l}\text { Fasilitas PPh ditanggung } \\
\text { pemerintah atas } \\
\text { penghasilan dari } \\
\text { penghapusan piutang } \\
\text { negara yang diterima } \\
\text { perusahaan daerah air } \\
\text { minum tertentu }\end{array}$ & $\begin{array}{l}\text { PMK no. } \\
\text { 195/PMK.010/2016 }\end{array}$ & $\mathrm{PPh}$ & DPP & - & 56 & 55 \\
\hline $\begin{array}{l}\text { Sisa lebih yang diterima atau } \\
\text { diperoleh badan atau } \\
\text { lembaga nirlaba yang } \\
\text { bergerak dalam bidang } \\
\text { pendidikan dan/atau bidang } \\
\text { penelitian dan } \\
\text { pengembangan }\end{array}$ & $\begin{array}{l}\text { Pasal } 4 \text { ayat (3) UU No. } \\
36 \text { Tahun } 2008 \\
\text { tentang PPh }\end{array}$ & $\mathrm{PPh}$ & DPP & 996 & 1.129 & 990 \\
\hline $\begin{array}{l}\text { Pengecualain sebagian } \\
\text { objek PPh bagi BPJS }\end{array}$ & PP No. 73 Tahun 2016 & PPh & DPP & 10.290 & 11.536 & 11.455 \\
\hline DTP Panas Bumi & $\begin{array}{l}\text { PMK } \\
\text { No.35/PMK.02/2010 }\end{array}$ & PPh & DPP & 1.849 & 1.646 & 1.838 \\
\hline $\begin{array}{l}\text { Penyederhanaan } \\
\text { penghitungan PPh atas } \\
\text { penghasilan usaha dengan } \\
\text { peredaran bruto tertentu }\end{array}$ & $\begin{array}{l}\text { Pasal } 4 \text { ayat (2) huruf e } \\
\text { dan pasal } 17 \text { ayat (7) } \\
\text { UU No. } 36 \text { Tahun } 2008\end{array}$ & $\mathrm{PPh}$ & Tarif & 6.978 & 9.575 & 16.123 \\
\hline $\begin{array}{l}\text { PPh Final atas penghasilan } \\
\text { jasa konstruksi }\end{array}$ & PP No. 51 Tahun 2008 & $\mathrm{PPh}$ & Tarif & 757 & 523 & 675 \\
\hline
\end{tabular}




\section{Hasil Granger Causality Test}

\begin{tabular}{||l|crr||}
\hline \hline Pairwise Granger Causality Tests & & & \\
Date: 09/16/20 Time: 08:18 & & & \\
Sample: 2015Q1 2019Q4 & & & \\
Lags: 4 & Obs & F-Statistic & Prob. \\
\hline \hline Null Hypothesis: & 15 & 0.22677 & 0.9137 \\
\hline \hline D(PDB) does not Granger Cause D(FASILITAS_PAJAK_SEMUA) & & 1.22431 & 0.3920 \\
D(FASILITAS_PAJAK_SEMUA) does not Granger Cause D(PDB) & & & \\
\hline
\end{tabular}

\begin{tabular}{|l|rrr||}
\hline \hline $\begin{array}{l}\text { Pairwise Granger Causality Tests } \\
\text { Date: 09/16/20 Time: 07:06 } \\
\text { Sample: } 2015 \mathrm{2} 1 \text { 2019Q4 } \\
\text { Lags: } 4\end{array}$ & & & \\
\hline \hline Null Hypothesis: & Obs & F-Statistic & Prob. \\
\hline \hline D(BELANJA PEMERINTAH) does not Granger Cause D(FASILITAS_PAJAK SEMUA) & 15 & 3.05824 & 0.1074 \\
D(FASILITAS_PAJAK_SEMUA) does not Granger Cause D(BELANJA_PEMERINTAH) & & 1.37954 & 0.3445 \\
\hline
\end{tabular}

\begin{tabular}{||lrrrr||}
\hline \hline Pairwise Granger Causality Tests & & & \\
Date: 09/16/20 Time: 05:55 & & & \\
Sample: 2015Q1 2019Q4 \\
Lags: 4
\end{tabular}

\begin{tabular}{|c|c|c|c|}
\hline $\begin{array}{l}\text { Pairwise Granger Causality Tests } \\
\text { Date: 09/16/20 Time: 07:11 } \\
\text { Sample: 2015Q1 2019Q4 } \\
\text { Lags: } 4\end{array}$ & & & \\
\hline Null Hypothesis: & Obs & F-Statistic & Prob. \\
\hline $\begin{array}{l}\text { D(PENERIMAAN NEGARA) does not Granger Cause D(FASILITAS PAJAK SEMUA) } \\
\text { D(FASILITAS_PAJAK_SEMUA) does not Granger Cause D(PENERIMAAN_NEGARA) }\end{array}$ & 15 & $\begin{array}{l}3.69248 \\
0.16160\end{array}$ & $\begin{array}{l}0.0755 \\
0.9503\end{array}$ \\
\hline
\end{tabular}

\begin{tabular}{|c|c|c|c|}
\hline $\begin{array}{l}\text { Pairwise Granger Causality Tests } \\
\text { Date: 09/16/20 Time: 06:53 } \\
\text { Sample: 2015Q1 2019Q4 } \\
\text { Lags: } 4\end{array}$ & & & \\
\hline Null Hypothesis: & Obs & F-Statistic & Prob. \\
\hline $\begin{array}{l}\text { D(HUTANG PEMERINTAH) does not Granger Cause D(FASILITAS PAJAK SEMUA) } \\
\text { D(FASILITAS_PAJAK_SEMUA) does not Granger Cause D(HUTANG_PEMERINTAH) }\end{array}$ & 15 & $\begin{array}{l}3.40108 \\
0.62476\end{array}$ & $\begin{array}{l}0.0884 \\
0.6622\end{array}$ \\
\hline
\end{tabular}

\begin{tabular}{||l|ccc||}
\hline Pairwise Granger Causality Tests & & & \\
Date: 09/16/20 Time: 06:32 & & & \\
Sample: 20152019 & & & \\
\hline Lags: 4 & Obs & F-Statistic & Prob. \\
\hline \hline Null Hypothesis: & 167772 & 0.00000 & 0.0000 \\
\hline \hline D(SUKU BUNGA_BI) does not Granger Cause D(FASILITAS_PAJAK_SEMUA) & & 0.00000 & 0.0000 \\
\hline D(FASILITAS_PAJAK_SEMUA) does not Granger Cause D(SUKU_BUNGA_BI) & & & \\
\hline
\end{tabular}

Pairwise Granger Causality Tests

Date: 09/16/20 Time: 08:49

Sample: 2015Q1 2019Q4

Lags: 4

\begin{tabular}{|lrrr|}
\hline \hline Null Hypothesis: & Obs & F-Statistic & Prob. \\
\hline \hline D(BELANJA PEMERINTAH) does not Granger Cause D(FASILITAS PAJAK DPP) & 15 & 1.37202 & 0.3466 \\
D(FASILITAS_PAJAK_DPP) does not Granger Cause D(BELANJA_PEMERINTAH) & & 0.43203 & 0.7819 \\
\hline \hline
\end{tabular}




\begin{tabular}{|c|c|c|c|}
\hline $\begin{array}{l}\text { Pairwise Granger Causality Tests } \\
\text { Date: 09/16/20 Time: 08:51 } \\
\text { Sample: 2015Q1 2019Q4 } \\
\text { Lags: } 4\end{array}$ & & & \\
\hline Null Hypothesis: & Obs & F-Statistic & Prob. \\
\hline $\begin{array}{l}\text { D(HUTANG PEMERINTAH) does not Granger Cause D(FASILITAS PAJAK DPP) } \\
\text { D(FASILITAS PAJAK DPP) does not Granger Cause D(HUTANG PEMERINTAH) }\end{array}$ & 15 & $\begin{array}{l}0.48021 \\
0.85691\end{array}$ & $\begin{array}{l}0.7509 \\
0.5389\end{array}$ \\
\hline
\end{tabular}

\begin{tabular}{|l|rrr||}
\hline \hline Pairwise Granger Causality Tests & & & \\
Date: 09/16/20 Time: 08:52 & & & \\
Sample: 2015Q1 2019Q4 \\
Lags: 4
\end{tabular}

\begin{tabular}{||l|crr||}
\hline Pairwise Granger Causality Tests & & & \\
Date: 09/16/20 Time: 08:55 & & & \\
Sample: 2015Q1 2019Q4 & & & \\
Lags: 4 & Obs & F-Statistic & Prob. \\
\hline \hline Null Hypothesis: & 15 & 0.04496 & 0.9951 \\
\hline \hline D(PDB) does not Granger Cause D(FASILITAS PAJAK_DPP) & & 1.74957 & 0.2572 \\
D(FASILITAS_PAJAK_DPP) does not Granger Cause D(PDB) & & & \\
\hline \hline
\end{tabular}

\begin{tabular}{|l|rrr|r|}
\hline \hline $\begin{array}{l}\text { Pairwise Granger Causality Tests } \\
\text { Date: 09/16/20 Time: 08:56 } \\
\text { Sample: } 2015 \mathrm{Q} 12019 \mathrm{4} 4 \\
\text { Lags: } 4\end{array}$ & & & & \\
\hline \hline Null Hypothesis: & Obs & F-Statistic & Prob. \\
\hline \hline D(PENERIMAAN_NEGARA) does not Granger Cause D(FASILITAS_PAJAK_DPP) & 15 & 2.46320 & 0.1553 \\
D(FASILITAS_PAJAK_DPP) does not Granger Cause D(PENERIMAAN_NEGARA) & & 0.20314 & 0.9276 \\
\hline
\end{tabular}

\begin{tabular}{|l|rrr||}
\hline Pairwise Granger Causality Tests & & & \\
Date: 09/16/20 Time: 08:58 \\
Sample: 2015Q1 2019Q4 \\
Lags: 4
\end{tabular}

\begin{tabular}{|c|c|c|c|}
\hline $\begin{array}{l}\text { Pairwise Granger Causality Tests } \\
\text { Date: 09/16/20 Time: 08:30 } \\
\text { Sample: 2015Q1 2019Q4 } \\
\text { Lags: } 4\end{array}$ & & & \\
\hline Null Hypothesis: & Obs & F-Statistic & Prob. \\
\hline $\begin{array}{l}\text { D(BELANJA PEMERINTAH) does not Granger Cause D(FASILITAS_PAJAK RATE) } \\
\text { D(FASILITAS_PAJAK_RATE) does not Granger Cause D(BELANJA_PEMERINTAH) }\end{array}$ & 15 & $\begin{array}{l}1.60734 \\
4.46325\end{array}$ & $\begin{array}{l}0.2871 \\
0.0517\end{array}$ \\
\hline
\end{tabular}

\begin{tabular}{|llrrrr||}
\hline \hline Pairwise Granger Causality Tests & & & & \\
Date: 09/16/20 Time: 08:32 \\
Sample: $2015 \mathrm{2} 1$ 2019Q4 \\
Lags: 4
\end{tabular}




\begin{tabular}{|lllll||}
\hline \hline Pairwise Granger Causality Tests & & & \\
Date: 09/16/20 Time: 08:33 & & & \\
Sample: 2015Q1 2019Q4 & & & \\
Lags: 4 & Obs & F-Statistic & Prob. \\
\hline \hline Null Hypothesis: & 15 & 0.61400 & 0.6685 \\
\hline \hline D(INFLASI) does not Granger Cause D(FASILITAS_PAJAK_RATE) & & 0.89100 & 0.5229 \\
\hline D(FASILITAS_PAJAK_RATE) does not Granger Cause D(INFLASI) & & & & \\
\hline
\end{tabular}

\begin{tabular}{|l|rrr||}
\hline \hline Pairwise Granger Causality Tests & & & \\
Date: 09/16/20 Time: 08:34 & & & \\
Sample: 2015Q1 2019Q4 & & & \\
Lags: 4 & Obs & F-Statistic & Prob. \\
\hline \hline Null Hypothesis: & 15 & 1.31540 & 0.3632 \\
\hline \hline D(PDB) does not Granger Cause D(FASILITAS_PAJAK_RATE) & & 0.95092 & 0.4961 \\
\hline D(FASILITAS_PAJAK_RATE) does not Granger Cause D(PDB) & & & \\
\hline
\end{tabular}

\begin{tabular}{|l|rrr||}
\hline \hline Pairwise Granger Causality Tests & & & \\
Date: 09/16/20 Time: $08: 37$ \\
Sample: $2015 \mathrm{2} 12019 \mathrm{Q} 4$ \\
Lags: 4
\end{tabular}

\begin{tabular}{|l|rrr||}
\hline \hline Pairwise Granger Causality Tests & & & \\
Date: 09/16/20 Time:08:40 \\
Sample: 2015Q1 2019Q4 \\
Lags: 4
\end{tabular}

